\title{
WYBRANE ZAGADNIENIA PRZEWOZU ZWIERZĄT I ICH ZAŁADUNKU W GOSPODARSTWIE W OCENIE ROLNIKÓW
}

\author{
Anna Grontkowska, Monika Gębska
}

Katedra Ekonomiki i Organizacji Przedsiębiorstw Szkoły Głównej Gospodarstwa Wiejskiej w Warszawie

Kierownik Katedry: prof. dr hab. Henryk Runowski

\begin{abstract}
Słowa kluczowe: dobrostan zwierząt, jakość mięsa, transport zwierząt, załadunek, ankieta Key words: animal welfare, meat quality, animal transport, loading, survey

S y n o p s i s. W artykule zaprezentowano opinie rolników dotyczące wybranych zagadnień związanych z załadunkiem zwierząt $\mathrm{w}$ gospodarstwie $\mathrm{i}$ ich transportem. Badania przeprowadzono z użyciem kwestionariusza ankiety w 2017 r. w 68 gospodarstwach, głównie utrzymujących bydło i trzodę chlewną. Rolnicy deklarowali częstsze wykorzystywanie specjalistycznych pojazdów do transportu zwierząt, należących do firm świadczących takie usługi (przewóz głównie do uboju) niż realizowanie przewozu zwierząt własnymi środkami transportu przez rolnika. Zdaniem respondentów, pomoc przy załadunku zwierząt była świadczona głównie przez rodzinę i kierowców pojazdów przewożących zwierzęta. Przy załadunku najczęściej stosowano rampy różnego rodzaju, głównie samochodowe $\mathrm{z}$ użyciem pełnych osłon bocznych (rzadziej windy), oraz różne urządzenia wspomagające przemieszczanie zwierząt. Załadunek przeważnie odbywał się w ciszy, chociaż odnotowano zróżnicowanie między załadunkiem trzody chlewnej a bydła. Świnie znacznie częściej wydawały głośne odgłosy. Nakłanianie zwierząt do ruchu przeważnie odbywało się głosem. W zakresie zainteresowania rolników losem zwierząt po ich wyjeździe z gospodarstwa odnotowano wyraźne zróżnicowanie.
\end{abstract}

\section{WSTĘP}

Problem zapewnienia dobrostanu zwierząt jest zagadnieniem bardzo szerokim, które można rozpatrywać w odniesieniu do uwarunkowań prawnych [Gębska 2014], ekonomicznych [Gębska i in. 2012] czy zachowań uczestników łańcucha żywnościowego [Malak-Rawlikowska, Gębska 2010]. Dotyczy on nie tylko prowadzenia produkcji zwierząt z poszanowaniem standardów, ale także pojawia się z różnym nasileniem przy ich transporcie. Przewóz żywych zwierząt jest koniecznością i dokonuje się nieustannie. Odnosi się przede wszystkim do transportu zwierząt realizowanego w sposób komercyjny, co wynika między innymi z postępującego procesu koncentracji i odmiennych kosztów produkcji w różnych częściach świata przy zastosowaniu konkretnych technologii i dotyczy zwierząt rzeźnych (w krajach Unii Europejskiej około 70-80\% ogółu przewozów zwierząt), hodowlanych, ale także użytkowanych sportowo i rekreacyjnie. Transport zwierząt odbywa się zarówno lokalnie, jak i na coraz większe odległości. Każdy przewóz naraża żywe zwierzęta na stres i dyskomfort. Uznaje się, że jest jednym z bardziej newralgicznych momentów w ich 
życiu. Zagwarantowanie właściwych warunków transportu zwierząt, tj. zapewnienie im dobrostanu podczas procesu załadunku, w trakcie przewożenia i rozładunku, jest ważne z powodów ekonomicznych, społecznych, środowiskowych. Odpowiednie warunki podczas transportu zwierząt chronią je przed nadmiernymi stratami energii oraz ograniczają ryzyko wystąpienia różnego rodzaju urazów, co w przypadku transportu do ubojni minimalizuje ryzyko wystąpienia wad mięsa, a w przypadku zwierząt hodowlanych - ryzyko utraty cennych osobników.

Proces transportu zwierząt jest wyjątkowo stresującym wydarzeniem w życiu zwierząt, a jest nieodzownym elementem łańcucha logistycznego [Fergusson 2008, Miranda-de la Lama $i$ in. 2014, Warriss 2000]. Stres jest wynikiem reakcji zwierząt na sytuację zupełnie nieznaną (rys. 1.). Zwierzęta są wystawione na działanie wielu nowych bodźców, takich jak:

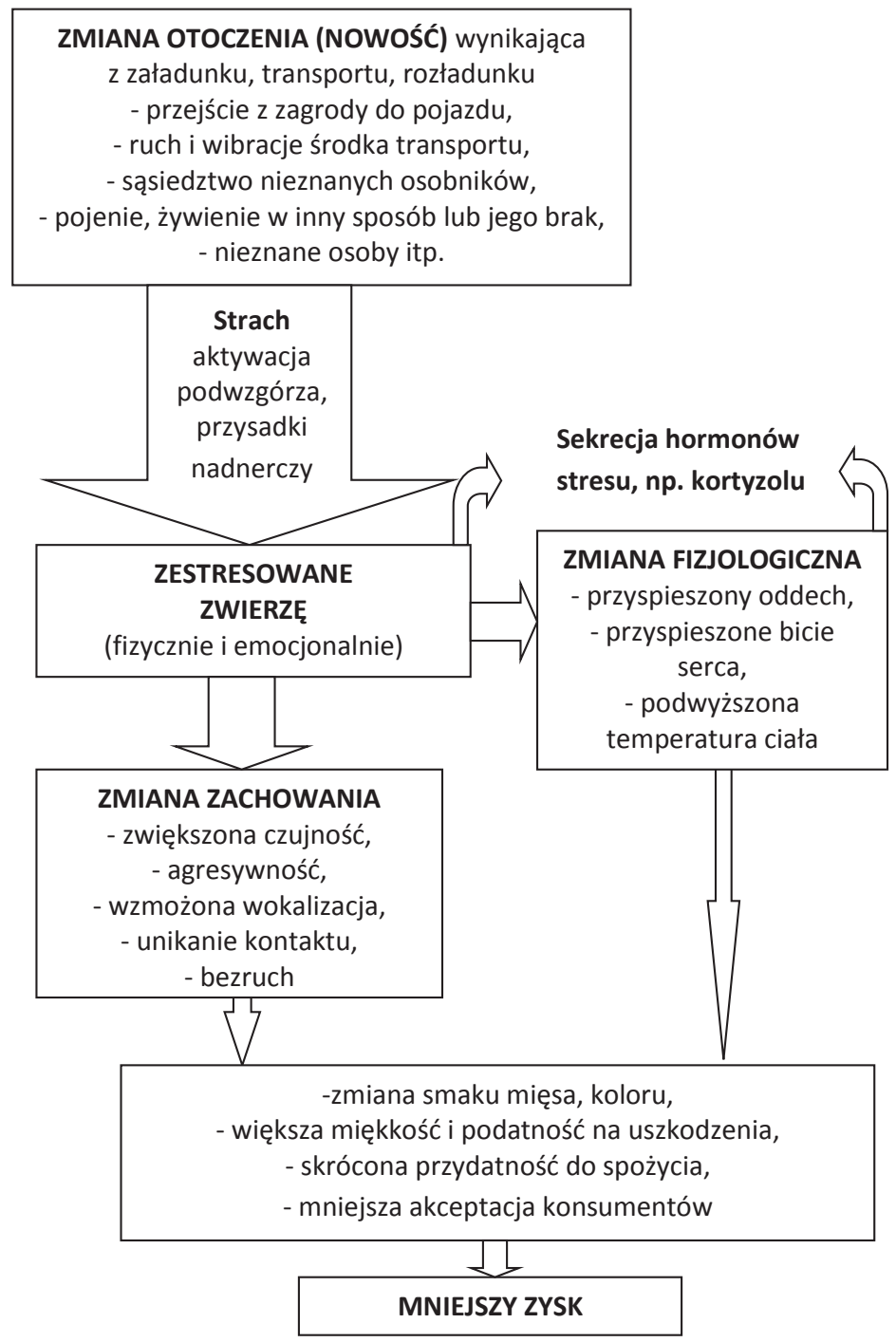

Rysunek 1.

Transport zwierząt i jego skutki Źródło: opracowanie własne. 
nieznane miejsce, ścisk, hałas, ruch i wibracje pojazdu, utrudniony dostęp do paszy i wody czy czynniki klimatyczne [Hemsworth, Coleman 1998, Knowles 1999, Swanson 2001].

Na poziom stresu wpływa też sposób postępowania ze zwierzętami [Broom 2000, Driessen i in. 2013]. Podczas transportu człowiek ma wpływ na sposób wyprowadzenia zwierząt z zagród do przyczepy, na ich załadunek, transport (prędkość i styl jazdy) i sposób rozładunku. Niewłaściwe postępowanie (np. brutalne, głośne) oraz zły stan obiektów (podłóg, ogrodzeń, ramp, pojazdów itp.) wpływa negatywnie lub wręcz uniemożliwia uzyskanie skutecznej interakcji ze zwierzętami podczas czynności niezbędnych do ich przemieszczania (łatwość ich obsługi) i osiągnięte efekty transportu. Ze względu na konsekwencje transportu, także ekonomiczne, należy zminimalizować niewłaściwe działania poprzez edukację ludzi, dbałość o sprzęt i dobrą organizację podróży [Driessen i in. 2013].

Osoby zajmujące się transportem żywych zwierząt lub zatrudnione do obsługi powinny być przeszkolone i wiedzieć, że zwierzęta, które nie mogą ustawić się zgodnie z preferencjami do kierunku jazdy, mają trudności z utrzymaniem równowagi w jadącym pojeździe [Tarrant $\mathrm{i}$ in. 1990], gdyż zwierzęta nie są przyzwyczajone do ruchów pojazdu w górę i dół, w trakcie pokonywania zakrętów na drodze czy hamowania lub ruszania pojazdu $\mathrm{z}$ miejsca. Niewłaściwa technika jazdy może powodować częstsze kontuzje zwierząt, ich przewracanie się czy stratowanie. Stwierdzono także, że zła jakość środków transportu wpływa negatywnie na dobrostan transportowanych zwierząt [Knowles 1999, Scheeren i in. 2014]. A.V. Weschenfelderab z zespołem wykazali, że nie wszystkie przyczepy są odpowiednie do transportu trzody na krótkie dystanse [Weschenfelderab i in. 2013]. Przyczepy trzypoziomowe z wewnętrznymi rampami powodują zmęczenie świń, co jest diagnozowane po ich uboju. Potencjalne przyczyny zmęczenia to obecność stromych ramp i zakrętów, które zmuszają świnie do wysiłku fizycznego podczas załadunku i rozładunku. Lepsze są przyczepy trzypoziomowe $\mathrm{z}$ windami do załadunku świń, co zapewnia lepszą kontrolę $\mathrm{i}$ łatwość obsługi świń przy załadunku i rozładunku. Nawet lokalizacja zwierząt w obrębie przyczepy może pogarszać te skutki transportu. W gorszej sytuacji są świnie wożone na wyższych poziomach przyczepy i między kołami (rys. 2.). Różnice między częściami pojazdu wynikają z koniecznego fizycznego wysiłku zwierząt niezbędnego do wejścia po rampie załadunkowej, aby dotrzeć do określonych części pojazdu, ale także różnic w sile wibracji lub panujących warunkach środowiskowych (temperatura, wilgotność względna i przepływ powietrza) [Scheeren i in. 2014].

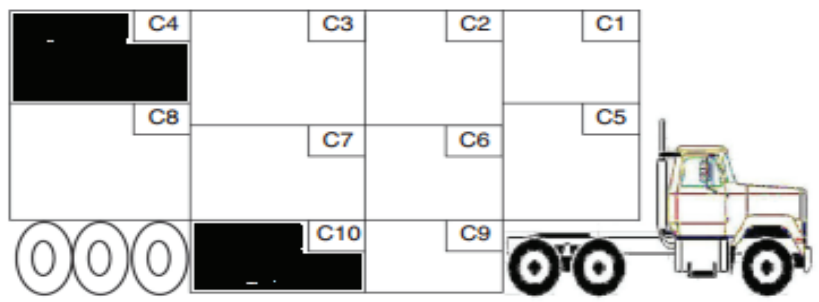

Rysunek 2. Warunki transportu w kanadyjskiej przyczepie do przewozu trzody chlewnej (na czarno zaznaczone przedziały o najgorszych warunkach C4 i C10)

Źródło: opracowanie własne na podstawie [Scheeren i in. 2014]. 
Jednocześnie wielu badaczy zwraca uwagę na to, że transport do ubojni nie powinien trwać zbyt długo [Seddon 2012], nie powinien zająć więcej niż 16 godzin [Mota-Rojas $\mathrm{i}$ in. 2006]. W badaniu przeprowadzonym przez Agnese Arduini z zespołem określano wpływ odległości podróży od 1 do $276 \mathrm{~km}$, pokazując, że każdy dystans może mieć negatywny wpływ na występowanie wad szynki [Arduini i in. 2014]. Większa częstość występowania wad była związana z transportem na małe odległości, co mogło wynikać z tego, że zwierzęta nie miały czasu na leżenie i regenerację sił po załadunku, ale także prawdopodobnie ze względu na pośpiech, w jakim pracują przewoźnicy, aby zrealizować wszystkie transporty zaplanowane na dany dzień. Ponadto uzyskane wyniki mogą być związane z niższą jakością dróg wiejskich, które stanowią większą część trasy w krótkich podróżach. Wydłużenie odległości transportu powyżej $170 \mathrm{~km}$ powodowało zwiększoną częstość występowania szynek bez wad. Częstość występowania problemów nie była proporcjonalna do zwiększenia dystansu przewozowego. Wyniki przeprowadzanych badań świadczyły o potrzebie usprawnienia obsługi przed ubojem (w tym transportu) w celu zwiększenia jakości szynek, zmniejszenia strat ekonomicznych związanych z niewłaściwymi praktykami przed ubojem i zwiększeniem dobrostanu zwierząt, aby był on tak dobry, jak to tylko możliwe [Arduini i in. 2014].

W przypadku przewożenia zwierząt do ubojni stres pogarsza dobrostan zwierząt i ma wpływ na jakość mięsa wytwarzanego ze zwierząt każdego z gatunków [Tarrant i in. 1992], gdyż może powodować uwalnianie hormonów stresu, co zmniejsza korzyści gospodarcze [Whiting 2000, Hulbert i in. 2011]. Behawioralna i fizjologiczna reakcja zwierzęcia przed ubojem, w tym sposób załadunku, transportu i rozładunku, wpływa na cechy odpowiadające za jakość mięsa: kolor, pH i teksturę [Muchenje i in. 2008, Lahucky i in. 1998]. Odnotowano, że zmiany behawioralne i fizjologiczne związane ze stresem obniżają jakość mięsa [Warriss 1992, Frimpong 2014] poprzez zubożenie glikogenu i podwyższone pH końcowe [O’Neill i in. 2006]. Wyniki badania przeprowadzonego przez M.B. Scheeren z zespołem potwierdziły, że niskie temperatury przyczyniają się do zwiększonego udziału stłuczonych tusz i że połączenie długiego czasu podróży (18 godzin) i warunków zimowych to główne czynniki występowania wieprzowiny o obniżonej ilości glikogenu ze względu na skutki długotrwałego oddziaływania stresu na mięśnie [Scheeren i in. 2014].

\section{CEL I METODY BADAWCZE}

Celem opracowania jest ustalenie sposobów postępowania ze zwierzętami w trakcie załadunku na środki transportu oraz charakterystyka wykorzystywanych do przewozu zwierząt pojazdów i urządzeń wspomagających proces załadunku i rozładunku. Badania z wykorzystaniem kwestionariusza ankiety przeprowadzono od października do grudnia 2017 roku w celowo dobranych gospodarstwach rolniczych prowadzących produkcję zwierzęcą (bez produkcji drobiu). Opinie rolników dotyczące aspektów związanych z realizowaniem przewozów zwierząt utrzymywanych w ich gospodarstwach przedstawiono w podziale na dwa gatunki zwierząt (bydło, trzoda chlewna). Określano podstawowe zagadnienia dotyczące załadunku zwierząt, zakres stosowania urządzeń wspomagających przemieszczanie zwierząt podczas załadunku, realizację samego załadunku zwierząt, ocenę własnego zainteresowania losami zwierząt podczas ich transportu i ich kondycją po dotarciu do miejsca docelowego. Uwzględniono opinie rolników utrzymujących bydło i trzodę chlewną. Ogółem dane o wybranych aspektach związanych z transportem zwierząt 
pochodziły z 68 gospodarstw, przy czym w opracowaniu szczegółowo zostały zaprezentowane opinie rolników zajmujących się produkcją trzody chlewnej oraz bydła, a w łącznym ujęciu w tabelach uwzględniono również pozostałe opinie rolników utrzymujących dwa gatunki zwierząt lub tylko jeden (np. owce czy konie). Gospodarstw utrzymujących tylko bydło było 28 , a tylko trzodę - 34. Prowadzenie produkcji określonego gatunku zwierząt warunkuje konkretne sposoby załadunku zwierząt i ich transportu. Także określony sposób użytkowania zwierząt wymusza wybór określonych środków transportu, inaczej odbywa się np. przewóz klaczy do stanowienia, a inaczej tuczników do rzeźni.

\section{WYNIKI BADAŃ}

Badane gospodarstwa charakteryzowały się zróżnicowaną powierzchnią od ok. 8 do 2000 ha użytków rolnych, a co za tym idzie i skalą produkcji zwierzęcej. Gospodarstw o powierzchni do 30 ha użytków rolnych było 32, od 31 do 100 ha użytków rolnych - 28 gospodarstw (łącznie udział tych gospodarstw wyniósł prawie 90\%) i powyżej 100 ha -8 gospodarstw. W tabeli 1. zestawiono informacje o sposobach realizacji transportu zwierząt zgodnie z deklaracjami rolników. Rolnicy mogli wskazać wiele sposobów dokonywania transportu. Łącznie wskazano 90 odpowiedzi, przy czym niektórzy rolnicy wskazywali zarówno transport własny, jak i realizowany przez firmę zewnętrzną, a inni nie udzielili odpowiedzi na to pytanie. Na korzystanie $\mathrm{z}$ transportu zwierząt prowadzonego przez zewnętrzne firmy wskazało 62 respondentów, w tym zawsze robiło tak $41 \%$ ogółu respondentów, a 19\% często. W przypadku rolników utrzymujących trzodę chlewną respondenci deklarujący, iż zawsze korzystali z usług firmy zewnętrznej do transportu, stanowili 55\% ogółu korzystających z takich usług, natomiast wśród rolników prowadzących chów bydła było to $43 \%$. Co czwarty rolnik deklarował, iż na stałe współpracuje z jednym przewoźnikiem zwierząt, nieco częściej dotyczyło to producentów żywca wieprzowego. Przewóz zwierząt własnymi środkami transportu deklarowało $37 \%$ ogółu respondentów, w tym zawsze - $16 \%$ ankietowanych, i dotyczyło to gospodarstw zajmujących się produkcją wieprzowiny dostarczaną do rzeźni lub do pośrednika.

Jeśli chodzi o miejsce docelowe przewozu, to dominował transport zwierząt do rzeźni (86,8\% ogółu gospodarstw). Szczegółowe informacje dotyczące deklaracji innych miejsc docelowego transportu zwierząt przedstawiono w tabeli 1 . W zestawieniu nie ujęto pojedynczych przewozów wskazywanych przez rolników, np. klaczy do stanowienia. Prawie $90 \%$ deklaracji przewozów z gospodarstw utrzymujących trzodę realizowano do rzeźni, w przypadku gospodarstw z bydłem było to $86 \%$. Niewielki odsetek gospodarstw utrzymujących trzodę (17,6\%) i wyraźnie większy z bydłem (46\%) to gospodarstwa zaopatrujące się w zwierzęta do chowu lub odsprzedające je do dalszego chowu i w związku z tym dokonywany był ich transport. W badanych gospodarstwach nie odnotowano przewozu zwierząt na targowiska.

Załadunek należy przeprowadzać profesjonalnie z wykorzystaniem właściwych urządzeń. Do załadunku zwierząt mogą być wykorzystywane pochylnie, rampy załadowcze lub windy. W Polsce najczęściej do załadunku wykorzystuje się pochylnie [Tereszkiewicz i in. 2017]. Zwierzęta jednak mają trudności w pokonywaniu pochyłości, niechętnie wchodzą na strome podejścia, ślizgają się i zawracają. Wykorzystanie do załadunku wind znacząco ogranicza niekorzystne reakcje zwierząt $\mathrm{i}$ w istotny sposób przyczynia się do obniżenia wskaźnika obrażeń, zmęczenia oraz upadków zwierząt [Ritter i in. 2009]. W procesie 
Tabela 1. Charakterystyka transportu zwierząt w opinii rolników według gatunków utrzymywanych zwierząt

\begin{tabular}{lccc}
\hline Wyszczególnienie & \multicolumn{3}{c}{ Liczba respondentów (N=68) } \\
\cline { 2 - 4 } & $\begin{array}{c}\text { z gospodarstw } \\
\text { z trzodą } \\
\text { chlewną }\end{array}$ & $\begin{array}{c}\text { z gospodarstw } \\
\text { z bydłem }\end{array}$ & ogółem \\
\hline Liczba gospodarstw & 34 & 28 & 68 \\
\hline Korzystanie z usług firmy zewnętrznej, w tym: & 29 & 28 & 62 \\
- zawsze & 16 & 12 & 28 \\
- często & 8 & 4 & 13 \\
- stały przewoźnik & 9 & 6 & 17 \\
\hline Przewóz zwierząt własnymi środkami & 10 & 13 & 25 \\
transportu, w tym: & 4 & & \\
- zawsze & 3 & 1 & 4 \\
- często & & & 4 \\
\hline Miejsce docelowego transportu zwierząt & 30 & 24 & 59 \\
- rzeźnia & 9 & 7 & 19 \\
- pośrednik & 6 & 13 & 21 \\
- dalszy chów & & & \\
\hline
\end{tabular}

Źródło: badania własne.

załadunku zwierząt, który jest uznawany za najbardziej stresujący dla zwierząt, stosuje się różnorodne sposoby mające na celu ułatwienie przemieszczania zwierząt. Ważne jest zapewnienie bezpieczeństwa zwierzętom, co oznacza stosowanie przy załadunku urządzeń niepowodujących zranień, zapewnienie właściwego oświetlenia i pozostałych warunków wymaganych podczas przemieszczania zwierząt, tak aby uniknąć ich zatrzymania się $i$ zawracania do kojców. W trakcie załadunku należy unikać hałasu i innych gwałtownych reakcji, nie wolno stosować przemocy wobec zwierząt. Do poganiania należy odpowiedzialnie i z umiarem korzystać z poganiaczy, w szczególności nie należy nadużywać elektrycznych poganiaczy. Należy zadbać o właściwe przygotowanie korytarzy do przepędzania zwierząt i pochylni do załadunku. By ułatwić zwierzętom wejście do pojazdu, należy zastosować właściwy kąt nachylenia pochylni oraz odpowiednie zabezpieczenie po bokach osłonami pełnymi lub ażurowymi o odpowiedniej konstrukcji i wytrzymałości, gwarantującymi zabezpieczenie przed urazami podczas załadunku. Charakterystykę wybranych elementów dotyczących procesu załadunku zwierząt $w$ badanych gospodarstwach przedstawiono w tabeli 2 .

Z przeprowadzonych badań wynika, że najczęściej do załadunku zwierząt stosowano rampy różnego rodzaju. Najczęściej rolnicy wskazywali rampy samochodowe, ich udział stanowił w odniesieniu do załadunku trzody chlewnej 56\%, natomiast przy załadunku bydła $-54 \%$. Pomimo iż rampy stosowano często, to tylko jeden respondent potwierdził wykonywanie pomiaru kąta nachylenia rampy. Stosunkowo rzadko do załadunku wykorzystywane były windy (udział rolników wskazujących ten sposób załadunku zwierząt wynosił $38 \%$, w tym $23,5 \%$ przy załadunku trzody chlewnej i $57 \%$ przy załadunku bydła), które są uważane za najlepszy sposób załadunku zwierząt ze względu na dobrostan 
Tabela 2. Charakterystyka rodzajów urządzeń i innych sposobów wspomagania przemieszczania zwierząt używanych podczas załadunku oraz ocena sposobu załadunku z wybranych punktów widzenia w opinii rolników

\begin{tabular}{|c|c|c|c|}
\hline \multirow{2}{*}{$\begin{array}{l}\text { Rodzaj urządzenia wykorzystanego do załadunku/ } \\
\text { wspomaganie załadunku zwierząt }\end{array}$} & \multicolumn{3}{|c|}{ Liczba respondentów $(\mathrm{N}=68)$} \\
\hline & $\begin{array}{l}\text { z gospodarstw } \\
\text { z trzodą } \\
\text { chlewną }\end{array}$ & $\begin{array}{l}\text { z gospodarstw } \\
\text { z bydłem }\end{array}$ & ogółem \\
\hline Rampa samochodowa & 19 & 15 & 38 \\
\hline Rampa ruchoma & 8 & 2 & 11 \\
\hline Nieruchoma rampa załadunkowa & 2 & 5 & 7 \\
\hline Winda & 8 & 16 & 26 \\
\hline Pełne osłony boczne & 19 & 12 & 33 \\
\hline Ażurowe osłony boczne & 3 & 10 & 14 \\
\hline Pomiar kąta nachylenia & - & 1 & 1 \\
\hline \multicolumn{4}{|c|}{ Nakłanianie zwierząt do przemieszczania przy załadunku } \\
\hline - głosem & 17 & 21 & 44 \\
\hline - płytą przepędową & 17 & 2 & 20 \\
\hline - rękoma (poklepywanie, głaskanie itp.) & 12 & 13 & 28 \\
\hline - specjalnym chwytem za określoną część ciała & 4 & 6 & 11 \\
\hline - elektrycznym poganiaczem & 5 & 9 & 14 \\
\hline \multicolumn{4}{|l|}{ Załadunek odbywa się } \\
\hline - w ciszy & 21 & 26 & 52 \\
\hline - zwierzęta często wydają głośne odgłosy & 11 & 1 & 13 \\
\hline \multicolumn{4}{|l|}{ Załadunek odbywa się } \\
\hline - bardzo szybko & 2 & 5 & 7 \\
\hline - w fizjologicznym tempie poruszania się zwierząt & 21 & 15 & 39 \\
\hline - powoli & 11 & 7 & 21 \\
\hline \multicolumn{4}{|l|}{ Załadunek odbywa się } \\
\hline - pojedynczo & - & 19 & 24 \\
\hline - w grupie po kilka sztuk & 30 & 4 & 35 \\
\hline - pojedynczo, po kilkanaście lub wszystkie na raz & 4 & 3 & 21 \\
\hline \multicolumn{4}{|l|}{ Zwierzęta przy przemieszczaniu potykają się } \\
\hline - czasami & 22 & 14 & 39 \\
\hline - nigdy & 8 & 11 & 22 \\
\hline - nie wiem, nie zwracam na to uwagi & 3 & 1 & 4 \\
\hline \multicolumn{4}{|c|}{ Zwierzęta zatrzymują się lub zawracają podczas załadunku } \\
\hline - czasami & 22 & 14 & 39 \\
\hline - nigdy & 2 & 11 & 15 \\
\hline - rzadko & - & 1 & 1 \\
\hline - zawsze & 1 & - & 1 \\
\hline
\end{tabular}

Źródło: badania własne. 
[Nanni-Costa $i$ in. 1999]. Urządzenia te pozwalają wyeliminować konieczność forsowania przez zwierzęta pochyłości. Rolników zapytano o wszystkie stosowane przy załadunku urządzenia, dlatego ich liczba jest większa niż liczba gospodarstw, albowiem przy różnych miejscach docelowych dotarcia zwierząt wykorzystywano do załadunku inne urządzenia.

Podczas załadunku zwierzęta najczęściej były nakłaniane do przemieszczenia się przy użyciu głosu, co wskazało dwóch na trzech ankietowanych (65\%). Drugi ważny sposób to użycie rąk poprzez poklepywanie, głaskanie, przynaglanie zwierząt do ruchu. Co piąty respondent deklarował używanie elektrycznych poganiaczy przy przemieszczaniu zwierząt do pojazdów, w których je następnie transportowano. Częściej takie urządzenia używano w stosunku do bydła niż świń. Rzadko deklarowano stosowanie specjalnego chwytu za określoną część ciała w celu nakłonienia zwierzęcia do ruchu, wskazało tak tylko 16\% ankietowanych, w tym rzadziej, bo $12 \%$ respondentów stosowało go w stosunku do świń, i nieco częściej w odniesieniu do bydła (21\%).

W opinii badanych rolników, załadunek najczęściej odbywał się w ciszy. Na taki przebieg załadunku wskazało $76 \%$ ankietowanych. W badaniu odnotowano zróżnicowanie między przebiegiem załadunku bydła i trzody chlewnej w tym zakresie. W przypadku załadunku trzody chlewnej zwierzęta wydawały głośne odgłosy w opinii co 3 respondenta (dla bydła odsetek wynosił około 4\%). W zakresie tempa załadunku rolnicy deklarowali zachowywanie naturalnego tempa poruszania się zwierząt (57\% wskazań, bez wyraźnego zróżnicowania między gatunkami zwierząt) lub powolne przemieszczanie zwierząt $\mathrm{w}$ kierunku pojazdu, w którym były transportowane. W gospodarstwach z trzodą chlewną powolny sposób załadunku deklarowało $32 \%$ rolników, z bydłem zaś - co czwarty rolnik. W opinii prawie $60 \%$ respondentów podczas załadunku zwierzęta czasami się potykają i zawracają. W tym zakresie nie odnotowano wyraźnych różnic przy załadunku trzody chlewnej i bydła. Natomiast w zależności od gatunku zwierząt inaczej odbywał się załadunek w odniesieniu do liczby zwierząt ładowanych w tym samym czasie jako jedna partia. Świnie przepędzano po kilka sztuk, natomiast bydło - pojedynczo, co jest zgodne z normami dobrostanu w tym zakresie. Należy zaznaczyć, iż w literaturze podkreśla się negatywny wpływ łączenia tuczników pochodzących z różnych stad na występowanie obrażeń ciała podczas transportu. Wykazano, że w grupach jednorodnych skala obrażeń była istotnie niższa w porównaniu z przewozami, w których wspólnie transportowano świnie z różnych gospodarstw. Na powstawanie obrażeń ma również wpływ płeć tuczników, sezon transportu, metoda załadunku, a także stan techniczny i wyposażenie pojazdów [Ritter i in. 2006]. Powstałe podczas transportu obrażenia ciała tuczników mają istotne znaczenie komercyjne. Obniżają klasę handlową i przydatność przetwórczą tusz. W podejściu technologicznym występowanie na tuszach zmian, które są wynikiem urazów doznanych w czasie transportu wyraźnie obniża ich wartość i atrakcyjność handlową. Tusze ze stwierdzonymi obrażeniami są również mniej wartościowe jako surowiec do produkcji elementów rozbiorowych i muszą być przeznaczone do wykrawania. Wyniki najnowszych badań wskazują, że udział tuczników z obrażeniami ciała wynosił ponad 57\% [Tereszkiewicz i in. 2017].

Podczas załadunku zwierząt zazwyczaj konieczna jest pomoc. W badaniach określono, iż najczęściej w załadunku zwierząt do pojazdu pomagały 2-3 osoby (tak wskazało 56,5\% ogółu ankietowanych). Byli to najczęściej członkowie rodziny (76,8\% ogółu wskazań) i kierowca $(52,2 \%)$, a znacznie rzadziej sąsiedzi (10\% ankietowanych) lub inne osoby towarzyszące kierowcy (pomocnik lub pomocnicy) lub pracownicy. Liczba osób uczestniczących w załadunku zwierząt wskazywana przez respondentów wahała się od 1 do 6 . Należy podkreślić, że liczba osób zaangażowanych zależy od liczby zwierząt, które mają 
Tabela 3. Ocena rolników dotycząca stanu środków transportu oraz własnego zainteresowania losami transportowanych zwierząt

\begin{tabular}{|c|c|c|c|}
\hline \multirow[t]{2}{*}{ Rodzaj opinii } & \multicolumn{3}{|c|}{ Liczba respondentów $(\mathrm{N}=68)$} \\
\hline & $\begin{array}{l}\text { z gospodarstw } \\
\text { z trzodą chlewną }\end{array}$ & $\begin{array}{l}\text { z gospodarstw } \\
\text { z bydłem }\end{array}$ & ogółem \\
\hline \multicolumn{4}{|c|}{ Stan środków transportu stosowanych przez przewoźników zewnętrznych } \\
\hline - właściwy & 30 & 27 & 62 \\
\hline - niewłaściwy & 1 & 1 & 3 \\
\hline \multicolumn{4}{|c|}{ Dowiadywanie się o stan zwierząt, w jakim dojechały na miejsce przeznaczenia } \\
\hline - zawsze & 7 & 3 & 12 \\
\hline - często & 2 & 2 & 4 \\
\hline - rzadko & 8 & 5 & 14 \\
\hline $\begin{array}{l}\text { - informacja dociera tylko, gdy zdarzyło się } \\
\text { coś złego podczas transportu }\end{array}$ & 8 & 3 & 11 \\
\hline - nigdy & 8 & 14 & 25 \\
\hline \multicolumn{4}{|c|}{$\begin{array}{l}\text { Deklaracja dotycząca chęci otrzymywania informacji o kondycji zwierząt, w jakim stanie } \\
\text { dojechały na miejsce przeznaczenia }\end{array}$} \\
\hline - nie interesuje mnie to & 9 & 13 & 24 \\
\hline - tak, rzadko & 3 & 2 & 6 \\
\hline - tak, czasami & 6 & 5 & 12 \\
\hline - tak, zawsze & 16 & 6 & 24 \\
\hline \multicolumn{4}{|l|}{ Doświadczenia z transportem zwierząt } \\
\hline - raczej pozytywne & 23 & 26 & 54 \\
\hline - raczej obojętne & 4 & 2 & 7 \\
\hline - raczej negatywne & 5 & - & 5 \\
\hline
\end{tabular}

Źródło: badania własne.

być przewożone, ale także samego sposobu załadunku. Inaczej odbywa się to przy załadunku na samochód z windą, a inaczej do jednoosiowej przyczepy użytej jako agregat z ciągnikiem. Podobne zależności dotyczą czasu załadunku.

Ważnym aspektem w procesie transportu zwierząt jest stan techniczny pojazdów i ich przygotowania do przewozu zwierząt. Oceny badanych rolników w tym zakresie zestawiono w tabeli 3. Z danych tych wynika, że ponad $90 \%$ respondentów oceniło stan techniczny pojazdów do przewozu zwierząt jako właściwy, a tylko 4,4\% jako niewłaściwy (nie wszyscy ankietowani udzielili odpowiedzi). Opinie rolników w zakresie własnego zainteresowania losami zwierząt odebranych z gospodarstwa były wyraźnie zróżnicowane, tylko $17,6 \%$ ankietowanych wskazało, że zawsze było zainteresowane przebiegiem przewozu zwierząt (w przypadku świń to $20 \%$ badanych producentów, a bydła jedynie co 10. producent), ale aż 37\% deklarowało, iż nigdy nie dowiadywało się o kondycję zwierząt po dotarciu do miejsca docelowego. Taka sytuacja w podziale na utrzymywane gatunki zwierząt dotyczyła połowy gospodarstw z bydłem i $23 \%$ gospodarstw z trzodą chlewną. Udział rolników wskazujących, że docierały do nich informacje o wystąpieniu nieprawidłowości podczas przewozu, wynosił 16,7\%, wyraźnie częściej dotyczył trans- 
portu trzody chlewnej niż bydła. W zakresie deklaracji dotyczącej chęci otrzymywania w przyszłości informacji o kondycji zwierząt, w jakim stanie dojechały na miejsce przeznaczenia, respondenci nie wykazywali zmian postawy. Zarówno 35,3\% rolników wskazało, że zawsze chciałoby mieć informacje o przebiegu transportu i kondycji zwierząt w miejscu docelowym, jak i tyle samo respondentów udzieliło odpowiedzi „nie interesuje mnie to”. W zakresie wartościowania doświadczeń związanych z transportem zwierząt dominowały oceny raczej pozytywne (prawie $80 \%$ wskazań). W ocenie opisowej respondenci podkreślali fachowość obsługi, profesjonalizm i sprawny przebieg załadunku zwierząt do pojazdów. Oceny negatywne odnotowano tylko w doświadczeniach z transportem trzody chlewnej. Wskazało je 14,7\% respondentów. W ocenach opisowych wskazywano przede wszystkim na nieprawidłową obsadę zwierząt w pojeździe. Należy pamiętać, że zarówno zwiększenie, jak i zmniejszenie obsady w stosunku do obowiązujących limitów powoduje wzrost udziału tuczników z obrażeniami ciała [Ritter i in. 2006, Pisula, Florowski 2009]. Zbyt małe zagęszczenie może być przyczyną wzrostu wskaźnika obrażeń, co wynika z trudności w utrzymaniu przez zwierzęta równowagi. $Z$ kolei zbyt duża obsada ogranicza ruch, utrudnia lub uniemożliwia przyjęcie pozycji leżącej i powoduje nasilenie walk o charakterze terytorialnym, co prowadzi do wzrostu udziału zwierząt wykazujących objawy zmęczenia potransportowego [Pisula, Florowski 2009]. Głównymi przyczynami obrażeń są odległość i czas transportu oraz wzajemne walki zwierząt pochodzących od różnych producentów i połączonych we wspólne grupy na czas transportu.

\section{PODSUMOWANIE}

Zagwarantowanie dobrostanu zwierząt bezpośrednio lub pośrednio warunkuje zdrowotność i produkcyjność zwierząt gospodarskich, a w efekcie wpływa na jakość otrzymywanych produktów pochodzenia zwierzęcego. Konieczność zapewnienia dobrostanu zwierząt pojawia się w uregulowaniach prawnych dotyczących hodowli, chowu, użytkowania, ale także przewozu zwierząt gospodarskich. Barierą we wdrażaniu założeń dobrostanu zwierząt $\mathrm{w}$ transporcie jest często brak dostatecznej wiedzy zaangażowanych podmiotów. W przewozie zwierząt szczególnie istotne są dobór właściwych środków transportu, sposób załadunku zwierząt, czas i warunki ich przewóz oraz przebieg rozładunku.

Przeprowadzone badania wykazały, że w badanych gospodarstwach do transportu zwierząt częściej wykorzystywano pojazdy firm zewnętrznych niż własne środki transportu będące w gospodarstwie. Stałą współpracę z konkretnym przewoźnikiem deklarował co czwarty rolnik, przy czym częściej dotyczyło to gospodarstw utrzymujących trzodę chlewna. Najczęściej realizowano transport zwierząt do uboju. W ocenie rolników załadunek zwierząt w badanych gospodarstwach odbywał się sprawnie, był realizowany z użyciem właściwych urządzeń pomocniczych i pojazdów zazwyczaj przygotowanych i przystosowanych do przewozu konkretnego gatunku zwierząt. Ogólnie ich ocena doświadczeń z transportem zwierząt była pozytywna (prawie 80\% odpowiedzi).

W obchodzeniu się ze zwierzętami należy zachować dbałość o ich dobrostan, realizować odpowiednie standardy załadunku i transportu, albowiem przekłada się to na efekty ekonomiczne i środowiskowe. Z przeprowadzonych badań wynika, że do załadunku najczęściej używano różnego rodzaju rampy, znacznie rzadziej stosowano windy. Przy załadunku zazwyczaj pomagało 2-3 osoby, a nakłanianie zwierząt do przemieszczania odbywało się głównie głosem i przez poklepywanie, głaskanie rękoma. Załadunek odbywał 
się zazwyczaj w ciszy, w fizjologicznym tempie poruszania zwierząt i w liczbie zgodnej z wymaganiami standardów dobrostanu w zależności od gatunku.

W zakresie zainteresowania respondentów przebiegiem transportu zwierząt poza gospodarstwem odnotowano zróżnicowane podejście: od chęci zdobycia pełnej wiedzy o tym procesie i kondycji zwierząt w miejscu docelowym do zupełnego braku zainteresowania. Respondenci zazwyczaj nie zmieniali zdania, co do zainteresowania efektami przewozów zwierząt, które będą realizowane w przyszłości.

Transport zwierząt ma duże znaczenie dla gospodarki, a popełniane podczas transportu błędy mają nieodwracalne skutki dla dobrostanu zwierząt, jakości tusz i mięsa. Niewłaściwe postępowanie ze zwierzętami niweluje wysiłki podejmowane przez rolników w zakresie poprawy dobrostanu zwierząt. Odpowiednia obsługa powinna być istotnym punktem uwagi podczas transportu. Wszyscy uczestnicy muszą zdać sobie sprawę, jak bardzo istotna jest interakcja między zwierzętami a obsługą oraz właściwa infrastruktura. Łatwość obsługi zwierząt zaczyna się od dobrego wyposażenia oraz szkoleń dla osób uczestniczących w transporcie żywych zwierząt, aby prawidłowo z nimi postępowały i rozumiały ich zachowanie.

\section{LITERATURA}

Arduini Agnese, Veronica Redaelli, Fabio Luzi, Stefania Dall'Olio, Stefania Pace, Leonardo Nanni Costa, 2014: Effect of Transport Distance and Season on Some Defects of Fresh Hams Destined for DPO, „Production Animals”, 4, p. 524-534, doi: 10.3390/ani4030524.

Broom Donald Maurice, 2000: Welfare assessment and problem areas during handling and transport. [in] Livestock Handling, Transport, ed. T. Grandin, $2^{\text {nd }}$ ed., Wallingford, UK, CABI, p. 43-61.

Driessen Bert, Ester Peeters, Jos Van Thielen, Sanne Van Beirendonck, 2013: Practical handling skills during road transport of fattening pigs from farm to slaughterhouse. A brief review. „Agricultural Sciences", 4, p. 756-761, http://dx.doi.org/10.4236/as.2013.412103, dostęp: 20.12.2017.

Ferguson Drewe M., Robin Dorothy Warner, 2008: Have we underestimated the impact of preslaughter stress on meat in ruminants?, „Meat Science”, 80, p. 12-19, doi: 10.1016/j.meatsci.2008.05.004.

Frimpong Samuel, Girma Gebresenbet, Emmanuel Bobobee, Elias D. Aklaku, Ibrahim Hamdu, 2014: Effect of Transportation and Pre-Slaughter Handling on Welfare and Meat Quality of Cattle: Case Study of Kumasi Abattoir, „Ghana Vet. Sci.”, 1, p. 174-191; doi:10.3390/vetsci1030174.

Gębska Monika, 2014: Challenges of the EU animal welfare legislation - implementation and enforcement in Poland, „Roczniki Naukowe Ekonomii Rolnictwa i Rozwoju Obszarów Wiejskich", t. 101, z. 4, s. 37-45.

Gębska Monika, Agata Malak-Rawlikowska, Edward Majewski, Anna Rekiel, 2012: Ocena finansowych skutków podnoszenia standardów dobrostanu trzody chlewnej w rolnictwie europejskim, „Roczniki Ekonomii Rolnictwa i Rozwoju Obszarów Wiejskich”, t. 99, z. 4, s. 89-104.

Hemsworth Paul H., Grahame J. Coleman, 1998: The stockperson and the productivity of intensively farmed animals, Wallingford, CT, CAB International, Human-Livestock Interactions.

Hulbert Lindsey E., Jonathan A. Carroll, i in. 2011: Innate immune responses of temperamental and calm cattle after transportation, „Vet. Immunol Immunopathol”, 143, p. 66-74, doi: 10.1016/j. vetimm.2011.06.025.

Knowles Toby G. 1999: A review of the road transportation of cattle, „Vet Rec.”, 144:197-201.

Kokoszka Stanisław, 2009: Postęp technologiczny a wydajność $i$ koszty $w$ transporcie zwierzat, „Problemy Inżynierii Rolniczej”, nr 4(30), s. 37-43.

Lahucky R., O. Palanska, J. Mojto, K. Zaujec, J. Huba, 1998: Effect of preslaughter handling on muscle glycogen level and selected meat quality traits in beef, „Meat Science”, 50, p. 389-93. 
Malak-Rawlikowska Agata, Monika Gębska, 2010: Postrzeganie dobrostanu zwierzat przez uczestników tańcucha żywnościowego w wybranych krajach Unii Europejskiej i w Polsce, ,Roczniki Nauk Rolniczych. Seria G. Ekonomika Rolnictwa", t. 97, z. 4, s. 135-148.

Miranda-de la Lama Genaro C., Morris Villarroel, Gustavo A. María, 2014: Livestock transport from the perspective of the pre-slaughter logistic chain: A review, „Meat Science”, 98, p. 9-20, doi: 10.1016/j.meatsci.2014.04.005.

Mota-Rojas D., M. Becerril i in., 2006: Effects of mid-summer transport duration on pre- and post-slaughter performance and pork quality in Mexico, „Meat Science”, 73, p. 404-412, doi: 10.16/j.meatsci.2005.11.012.

Muchenje V., K. Dzama, M. Chimonyo, J.G. Raats, P.E. Strydom, 2008: Meat quality of Nguni, Bonsmara and Aberdeen Angus steers raised on natural pasture in the Eastern Cape, South Africa, „Meat Science”, 79, p. 20-28, doi: 10.1016/j.meatsci.2007.07.026.

Nanni Costa Leonardo, Domenico Pietro Lo Fiego, Stefania Dall'Olio, Roberta Davoli, Vincenzo Carlo Russ, 1999: Influence of loading method and stocking density during transport on meat and dry-cured ham quality in pigs with different halothane genotypes, „Meat Science”, vol. 51, p. 391-399.

O'Neill H.A., E.C. Webb, L. Frylinck, P.E. Strydom, 2006: The stress responsiveness of three different breed types and the effect on ultimate $\mathrm{pH}$ and meat colour. Proceedings of $52^{\text {nd }}$ International Congress of Meat Science and Technology, 13 to 18 August 2006. Dublin, Ireland. p. 181-182.

Pisula Andrzej, Tomasz Florowski, 2008: Zmiany ilościowe i jakościowe mięsa w trakcie jego pozyskiwania i przetwarzania, „Gospodarka Mięsna”, vol. 2, s. 8-14.

Ritter Matthew i in., 2009: Transport Losses in Market Weight Pigs: I. A Review of Definitions, Incidence, and Economic Impact, „Animal Scientist”, vol. 25, p. 1080-7446.

Ritter Matthew, Martin Ellis, Janine Brinkmann, Jacob DeDecker, Kerry Keffaber, Edward Kocher, Benjamin Peterson, Johannes Schlipf, Bradley Wolter, 2006: Effect of floor space during transport of market-weight pigs on the incidence of transport losses at the packing plant and relationships between transport conditions and losses, „Journal of Animal Science”, vol. 84, p. 2856-2864.

Scheeren M.B., H.W. Gonyou, J. Brown, A.V. Weschenfelder, L. Faucitano, 2014: Effects of transport time and location within truck on skin bruises and meat quality of market weight pigs in two seasons, „Can. J. Anim. Sci.”, 94, p. 7178, doi:10.4141/CJAS2013-136.

Seddon Y.M., J. Brown, T. Crowe, R. Bergeron, T.M. Widowski, J.A. Correa, L. Faucitano, H.W. Gonyou, 2012: Truck compartment and trip duration affect stress of pigs transported under Canadian conditions, ,J. Anim. Sci.”, 90 (Supl. 3), p. 255.

Swanson J.C., J. Morrow-Tesch, 2001: Cattle transport: Historical, research, and future perspectives, ,J. Anim Sci.”, 79 (E supl.), p. 102-109.

Tarrant P.V. 1990: Transportation of cattle by road, „Appl. Anim. Behav. Sci.”, 28, p. 153-170.

Tarrant P.V., Kenny F.J., Harrington D., Murphy M. 1992: Long distance transportation of steers to slaughter: effect of stocking density on physiology, behaviour, and carcass quality, „Livest. Prod. Sci.", 30, p. 223-238, doi: 10.1016/SO301-6226(06)80012-6.

Tereszkiewicz Krzysztof, Piotr Molenda, Karolina Choroszy, Łukasz Kulig, 2017: Warunki transportu i kondycja tuczników z dostaw bezpośrednich do zakładów ubojowych na Podkarpaciu. „Autobusy”, vol. 6, s. 1574-1578.

Warriss P.D. 1992: Animal Welfare - handling animals before slaughter and the consequences for welfare and product quality, July issue, Oxon, England, Meat Focus International, p. 135-138.

Warriss P.D. 2000: Meat Science: An introductory text, Wallingford, UK, CAB International, p. 312.

Weschenfelderab A.V., S. Torreya, N. Devillersa, T. Crowec, A. Bassolsd, Y. Sacod, M. Piñeiroe, L. Saucierb, L. Faucitanoa, 2013: Effects of trailer design on animal welfare parameters and carcass and meat quality of three Pietrain crosses being transported over a short distance, „Livestock Science”, 157, p. 234-244.

Whiting T.L., 2000: Comparison of minimum space allowance standards for transportation of cattle by road from 8 authorities, „Can. Vet. J.”, 41, p. 855-860. 


\title{
Anna Grontkowska, Monika Gębska
}

\section{SELECTED ISSUES OF TRANSPORTATION AND LOADING ANIMALS ON THE FARM IN THE OPINION OF FARMERS}

\begin{abstract}
Summary
The paper aims to present opinions of farmers on selected issues related to transportation and loading animals on the farm. The research was conducted in 2017 using a questionnaire survey in 68 farms, mainly keeping cattle and pigs. Farmers declared more frequent use of specialized vehicles for transporting animals that provide such services (mainly for slaughter) than their own means of transport. According to the respondents, the family and drivers of vehicles transporting animals provided evidence of assistance in loading animals. During the loading, ramps of various types were used most often, mainly car with full covers (less frequent elevators), and various devices supporting the movement of animals. Loading usually took place in silence, although there was a difference between the loading of pigs and cattle. Pigs made loud noises much more often, and the urging of animals to move is usually done by voice. In terms of interest in the fate of animals leaving the farm, there was a significant difference.
\end{abstract}

Adres do korespondencji:

Dr inż. Anna Grontkowska (orcid.org/0000-0002-7286-8496) Dr inż. Monika Gębska (orcid.org/0000-0001-6196-5904)

Szkoła Główna Gospodarstwa Wiejskiego w Warszawie Katedra Ekonomiki i Organizacji Przedsiębiorstw 02-787 Warszawa, ul. Nowoursynowska 166 e-mail: anna_grontkowska@sggw.pl monika_gębska@sggw.pl 